\title{
Extrarenal calyces with ureteropelvic junction type obstruction
}

\author{
Vikram Khanna, ${ }^{1}$ Kashish Khanna (1) , ${ }^{2}$ Arun Chauhan, ${ }^{1}$ Rohit Kapoor ${ }^{1}$
}

${ }^{1}$ Pediatric Surgery, Lady Hardinge Medical College and Kalawati Saran Children's Hospital, New Delhi, Delhi, India ${ }^{2}$ Pediatric Surgery, All India Institute of Medical Sciences, New Delhi, Delhi, India

Correspondence to Dr Kashish Khanna; kash.modern@gmail.com

Accepted 7 February 2022

\section{Check for updates}

(C) BMJ Publishing Group Limited 2022. No commercial re-use. See rights and permissions. Published by BMJ.

To cite: Khanna V, Khanna K, Chauhan $\mathrm{A}$, et al. BMJ Case Rep 2022;15:e248445 doi:10.1136/bcr-2021248445

\section{DESCRIPTION}

Extrarenal calyces (ERC) is a rare renal anomaly and can present with a solitary clinical symptom of flank pain, or as a complex radiological finding or a confusing intraoperative finding. Esiendrath first described the anomaly in 1925 and less than 50 cases are reported in literature worldwide. ${ }^{1}$ In this anomaly the major calyces and pelvis lie outside the kidney and it is often associated with other renal anomalies like hydronephrosis due to ureteropelvic junction obstruction (UPJO), dysplasia and ectopic kidney. ${ }^{2}$

Herein, we present a case of ERC in a 10 -year-old boy presenting with pain and a lump in the left flank. Ultrasound showed a hydronephrotic left kidney, size $11.3 \times 5.1 \mathrm{~cm}$ with thinned out cortex and dilated pelvis likely due to UPJO. Right kidney was normal. The renal dynamic scan confirmed severe hydronephrosis and poor function (9\%) in the left kidney. Open left pyeloplasty was planned for the patient. Consent for left nephrouretrectomy was also taken in view of poor function. No other imaging was performed.

An anterior flank extraperitoneal approach was used to access the left kidney. Intraoperatively, the ballooned kidney was decompressed and

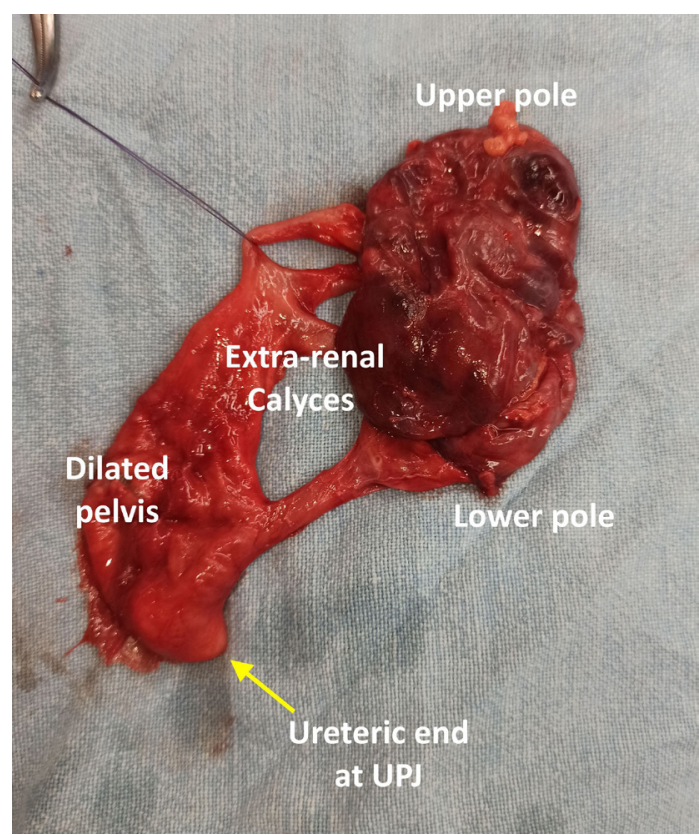

Figure 1 Nephrouretrectomy specimen of left kidney showing papery thin parenchyma and four major calyces draining into the dilated pelvis, the extrarenal calyces (ERC).

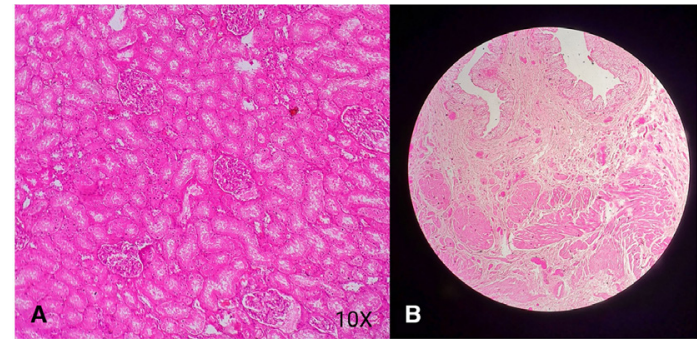

Figure 2 (A) Microscopic sections(10x) from kidney showing hydropic changes and (B) section from ureter showing thickened muscular wall.

$150 \mathrm{~mL}$ of urine was drained. Abnormal intraoperative findings in form of multiple tubular structures (1-3 cm in length) arising from the kidney and then draining into a dilated sac with nonidentification of the ureter during initial dissection pointed towards a developmental anomaly of the pelvicalyceal system.

On initial examination, it seemed like a variant of renal duplication anomaly. On further dissection, four major calyces were clearly identified which emerged from the kidney draining into the dilated pelvis and the ureter was attached to the lowermost part of renal pelvis and narrowing at UPJ was present.

In view of poor renal function (9\%), papery thin parenchyma and complex anatomy, left nephrouretrectomy was performed (figure 1). The histopathological finding showed a markedly dilated pelvicalyceal system with thickened ureter and focal hydropic changes in the kidney (figure 2). In the case with the poor function $(<10 \%)$ but a good robust parenchyma and comparable renal size, we would have done pyeloplasty.

The disparity in the rate of growth that is, rapid branching of ureteric bud into calyces before it coalesces with the metanephric blastema or the delayed differentiation of the metanephric tissue has been postulated as the cause for the origin of

\section{Learning points}

Multiple tubular calyces which lay outside the kidney should alert the surgeon towards the possibility of extrarenal calyces (ERC).

- ERC anatomy can be confused with renal duplication anomalies.

- ERC may be associated with ureteropelvic junction obstruction type of hydronephrosis. 
ERC anomaly. ${ }^{3}$ The child is in our follow-up for 13 months and has been symptom free.

In such cases, if there is preoperative suspicion of ERC, an intravenous pyelography or an MR urogram can definitely prove helpful to delineate the complex anatomy and functional status of the renal moiety beforehand.

Acknowledgements The authors sincerely thank Dr P. Lalita Jyotsna, Associate Professor, Department of Pathology at Lady Hardinge Medical College, New Delhi for providing the histology findings for this case.

Contributors The child was admitted under the care of VK. The workup, investigations and postoperative care and follow-up were done by VK, AC and RK. $\mathrm{KK}, \mathrm{VK}$ and RK were involved in writing the manuscript. All authors were involved in the final editing of the manuscript.

Funding The authors have not declared a specific grant for this research from any funding agency in the public, commercial or not-for-profit sectors.

Competing interests None declared.
Patient consent for publication Consent obtained from parent(s)/ guardian(s)

Provenance and peer review Not commissioned; externally peer reviewed.

Case reports provide a valuable learning resource for the scientific community and can indicate areas of interest for future research. They should not be used in isolation to guide treatment choices or public health policy.

\section{ORCID iD}

Kashish Khanna http://orcid.org/0000-0003-3400-3253

\section{REFERENCES}

1 Pontes JE, Rattner WH. Extrarenal collecting system presenting as an abdominal mass in a child. J Urol 1973;110:585-7.

2 Raghunath BV, Narendra BM, Gowrishankar BC, et al. Extrarenal calyces associated with pelviureteric junction obstruction: a case report of a rare anomaly. I Indian Assoc Pediatr Surg 2012;17:124-5.

3 Pagliere HA, Morici P. Cálices extrarrenales. Rev Argent Urol 1976;44:24-6.

Copyright 2022 BMJ Publishing Group. All rights reserved. For permission to reuse any of this content visit

https://www.bmj.com/company/products-services/rights-and-licensing/permissions/

BMJ Case Report Fellows may re-use this article for personal use and teaching without any further permission.

Become a Fellow of BMJ Case Reports today and you can:

- Submit as many cases as you like

- Enjoy fast sympathetic peer review and rapid publication of accepted articles

- Access all the published articles

Re-use any of the published material for personal use and teaching without further permission

Customer Service

If you have any further queries about your subscription, please contact our customer services team on +44 (0) 2071111105 or via email at support@bmj.com.

Visit casereports.bmj.com for more articles like this and to become a Fellow 